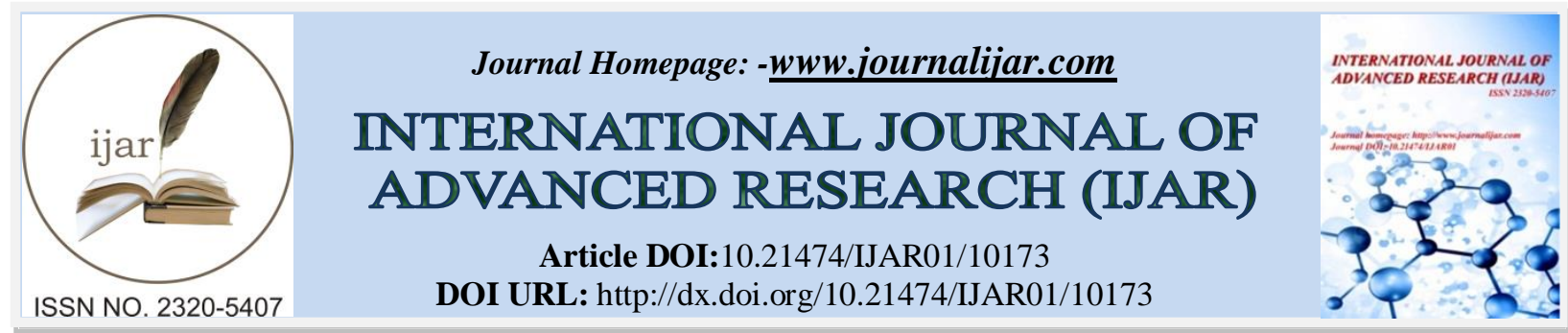

\title{
RESEARCH ARTICLE \\ A STUDY TO ASSESS THE LEVEL OF ANXIETY AMONG CLIENTS UNDERGOING UPPER GASTRO ENDOSCOPY AT INDIRA GANDHI GOVT. GENERAL HOSPITAL \& POST GRADUATE INSTITUTE , PUDUCHERRY \\ P.Selvakumar ${ }^{1}$ and Prof. A. Felicia Chitra ${ }^{2}$ \\ 1.M.Sc $(\mathrm{N})$, College of Nursing, MTPG \& RIHS, Puducherry \\ 2. Principal cum HOD in Medical Surgical Dept., College of Nursing, MTPG \& RIHS, Puducherry.
}

\section{Manuscript Info}

Manuscript History

Received: 05 October 2019

Final Accepted: 07 November 2019

Published: December 2019

\begin{abstract}
Anxiety is a common problem in patients undergoing invasive medical procedures. Endoscopy is a demanding procedure and requires a patient's good cooperation for successful results. Quantitative research approach with descriptive research design was adopted to achieve the aim of the present study. The study was carried out at IGGGH \& PGI, Puducherry, to assess the level of anxiety among clients undergoing upper gastro endoscopy. The demographic data was collected from the clients who fulfill the inclusion criteria. The level of anxiety was assessed by Strait Trait Anxiety Inventory - Y- 1 (STAI-Y-1) scale. The conceptual frame work of the study was based on Imogene king's proposed goal attainment model (1971) of nursing. 30 Samples were selected by Simple random technique by using lottery method. The study findings revealed that, Majority $(33.3 \%$ ) of the clients were belongs to the age group of $31-40$ years, among that most of them were male and graduates, $93 \%$ were residing in urban, $50 \%$ earns between Rs.10, 001 - Rs. 15, 000.Greater part (40\%) of the clients came for endoscopy with other gastro intestinal symptoms and $55 \%$ of the client heard through family members and $45 \%$ obtained the information through friends. According to the level of anxiety, majority $(93 \%)$ of them shows severe anxiety and $7 \%$ shows moderate level of anxiety. There was no statistically significant association between the level of anxiety with the selected demographic variables such as age, gender and educational status, residence, income and reason for endoscopy.It concludes, majority (93\%) of them shows severe anxiety and $7 \%$ shows moderate level of anxiety towards the procedure. Hence, it concluded that most of the clients were severely anxious about the procedure
\end{abstract}

Copy Right, IJAR, 2019,. All rights reserved.

\section{Introduction:-}

The word "Endoscopy" is derived from the Greek word Endo (means inside) and "spoke in" (means to examine). Endoscopy means direct visualization of the interior aspects of the gastro intestinal tract starting from pharynx to duodenum through mouth by means of an endoscopy. Endoscopy contains multiple channels that allow for air insufflations, irrigation, fluid aspiration and the passage of special instrument .These instruments include biopsy forceps, cytology brushes; needles wire baskets, laser probes and electro cautery shares.

Corresponding Author:- P.Selvakumar, M.Sc(N), College of Nursing, MTPG \& RIHS, Puducherry 
Upper gastrointestinal endoscopy is a widely used procedure for diagnosis and treatment of upper gastrointestinal diseases. Although it is considered as a safe and well-tolerated procedure, significant discomfort has been noted in patients undergoing endoscopy without sedation. (Aduful, 2007)

Gastro intestinal Cancer is one of the leading causes of adult deaths worldwide. In south India, Stomach cancer is the third most common cancer. So the technology goes throughout our life. But still we are lack in early and effective diagnosis. People were scared by seeing the huge apparatus used for diagnosis and hesitate to come forward. Endoscopy has become a mandatory investigation in Gastroenterology is early detection of GI Cancers, which is a major health problem in our country ( Kathiravan, 2011).

Anxiety is an emotional response to a threatening situation and it is generally agreed that hospitalization and associated procedures produce various threats including possible disability, coping with new social situations, and deprivation of normal freedom results in alteration in the physiological parameters (Auden, 2010)

Upper gastrointestinal endoscopy can be an uncomfortable, unpleasant and painful procedure. Patient acceptability of endoscopic procedures may be reduced due to fears of embarrassment, discomfort, and worry which in turn reflect disturbances in physiological response.

Adequate information about endoscopic procedures may reduce anxiety; fear and worrying that may lead to good co-operation and active willing to undergo the procedure. So as a nurse and health care personnel it is our role to explain the procedure to the patient, there by reduces pre-procedural anxiety there by maintains stable physiological response and gain co-operation which will adversely helpful in early diagnosis and for effective treatment.

\section{Need For The Study:-}

Upper GI endoscopy in combination with biopsy through endoscopy plays an important role in the early diagnosis of GI disorders and provides an opportunity for a broad range of treatment options and cure.

Anxiety is a common problem in patients undergoing invasive medical procedures. Endoscopy is a demanding procedure and requires a patient's good cooperation for successful results. Anxiety before upper gastrointestinal endoscopy may have adverse consequences and can sometimes hamper successful completion of the procedure (Mahmut Arabul , 2013)

A person's cognitive processes can alter the perceived meaning of a threatening stimulus and reduce the physiological response. The best way to reduce the anxiety of the patient is to educate about the procedure and provide psychological support during the procedure stated by Roshan John (2012), in Cognitive theory of Emotion.

Abdominal pain and gastro esophageal reflux was the most common GI symptom at USA. There were 6.9 million underwent upper endoscopy, 11.5 million lower endoscopy, and 228,000 billiary endoscopies performed in 2009. The total cost for outpatient GI endoscopy examinations was $\$ 32.4$ billion. It concludes, GI diseases are the source of substantial morbidity, mortality, and cost in the United States. ( Peery, 2012 )

In India, $60 \%-70 \%$ of people were suffering from digestive disorders and cause significant mortality. Narrated $50 \%$ of the rural populations are unaware of the diagnostic procedure and not willing to come forward because of anxiety. Education of the patient prior to the procedure about the things they will see, feel and hear during the procedure has a significant role in reducing anxiety and fear. (Pignone, 2012)

In Tamilnadu, around 50-60 \% of people suffering from digestive disorders. Esophageal and stomach cancers are the third and fourth most common cancers in our country. Early detection and treatment reduces morbidity and mortality. The latest fibrotic endoscopes allow us to obtain targeted biopsies and other therapeutic procedures effectively. (Dr. George Chandy, MIOT Hospital, Chennai,)

In Puducherry, more than 60 to $70 \%$ of patients suffered from alcohol-related gastroenterological disorders and has carried out 500 endoscopy procedures in the last few months at Pondicherry Institute of Medical Sciences.Awareness should be created through the media regarding benefits of early detection with endoscopy. (Thomas Alexander, Hindu, 2010) 
A study on Mucosal Biopsies through upper gastro endoscopy among 192 cases at sri venkateshwaraa medical college hospital and research centre, pondicherry. It reveals that upper GI endoscopy helps in early detection of mucosal lesions and diagnosis of the carcinomas at early stage leading to early clinical management. (Sandhya Panjeta Gulia , 2012)

During the clinical experience the Investigator has observed that many patients scheduled for upper gastrointestinal endoscopy are having anxiety, as a consequence of the procedure has to be repeated, or the patient experiences more discomfort during the procedure.. Hence the investigator felt that pre-procedural teaching will reduce anxiety level and increase self-confidence and co-operation to the procedure. So, the researcher selected this topic in order to create awareness and make the people to lead the life happily by early detection of GI disorder through upper gastro endoscopy.

\section{Statement of the problem:}

A study to assess the level of anxiety among clients undergoing upper gastro endoscopy at IGGGH \& PGI , Puducherry.

\section{Objectives:-}

1. To assess the level of anxiety among clients undergoing upper gastro endoscopy.

2. To associate the level of anxiety with selected demographic variables.

\section{Review Of Literature:}

Review of literature is a key step in research process. It is a body of text that aims to review the critical points of current knowledge including substantive findings as well as theoretical and methodological contributions to a particular topic.

A literature review is a written summary of the state of existing knowledge on the research problem. The task of reviewing research literature involves the identification, selection, critical analysis and written description of the existing information on a topic. (Polit and Hungler, 2004)

An Existing review of literature to gain insight into the selected problem is depicted under the following sequences

Sec A : Literature related to magnitude of upper gastro endoscopy

Sec B : Literature related to Upper gastro endoscopy on anxiety level

\section{Research Methodology:-}

Research approach:

Quantitative research approach

\section{Research design:}

In the present study the descriptive research design was adopted.

\section{Setting of The Study:}

The study was conducted at IGGGH \& PGI, Puducherry.

\section{Population of the study:}

The population for the present study was the Clients planned to undergoing upper gastro endoscopic procedure at IGGGH \& PGI, Puducherry.

\section{Variables:}

Dependent variable- Level of Anxiety

\section{Sample:}

Sample for the present study were the clients planned to undergoing upper gastro endoscopic procedure and who fulfils the inclusion criteria.

\section{Sample size:}

30 study participants were selected for the study. 


\section{Sampling technique:}

Simple random sampling technique was adopted by using lottery method.

\section{Criteria for selection of sample}

Inclusion crteria:

1. Patient those who are posted for endoscopy procedure.

2. Patient those who can understand and speak Tamil.

3. Patient who are willing to participate in the study

4. Patient available at the time of data collection.

5. Patient age above 20 and below 61 years.

\section{Exclusion criteria:}

1. Patient who are associated with systemic complications like coronary heart

2. disease, epilepsy etc.,

3. Mentally ill patient.

4. Previous experience of endoscopy

\section{Methods of data collection:-}

Data collection was carried out within the given period of 1 weeks at IGGGH \& PGI, puducherry. Self introduction and information about the study was explained to the participants, so as to get co-operation in the procedure of data collection. Date will be collected in two phases,

First phase:

Demographic data was collected from the client

Second phase:

Level of anxiety was assessed by STAI - Y- 1 scale before the procedure.

\section{Organisation And Presentation Of Data:}

The analysis of data was organized and presented under the following sections.

Section A: Distribution of the clients undergoing upper gastro endoscopy according to their demographic variables Section B:Distribution of the level of anxiety among the clients undergoing upper gastro endoscopy . Section C:Association between the level of anxiety with selected demographic variables.Section A

\section{Distribution Of The Clients Undergoing Upper Gastro Endoscopy According To Their Demographic} Variables:

Table 4.1.1:- Distribution of the client to their age, gender and educational status. N=30

\section{DEMOGRAPHIC VARIABLES}

\begin{tabular}{|l|c|c|}
\cline { 2 - 3 } & f & \% \\
\hline AGE & & 63.3 \\
\hline $31-30$ years & 19 & 36.7 \\
\hline $41-50$ years & 11 & - \\
\hline $51-60$ years & - & - \\
\hline & - & \\
\hline GENDER & & 46.7 \\
\hline Male & 14 & 53.3 \\
\hline Eemale & 16 & \\
EDUCATIONAL STATUS & & \\
\hline
\end{tabular}




\begin{tabular}{|l|c|c|}
\hline Primary & 27 & 90 \\
\hline Secondary & 1 & 3.3 \\
\hline Graduates & 2 & 6.7 \\
\hline Post graduates & - & - \\
\hline
\end{tabular}

Table 4.1.1 shows the distribution of the client to their age, gender and educational status. It depicts that majority ( $33.3 \%$ )of the clients were belongs to the age group of $31-40$ years, among that most of them were male and graduates.

Table 4.1.2:-Distribution of the clients according to the residence area .

\begin{tabular}{|l|c|c|}
\hline Residence & f & \% \\
\hline Rural & 21 & 70 \\
\hline Urban & 9 & 30 \\
\hline
\end{tabular}

\section{Residence:-}

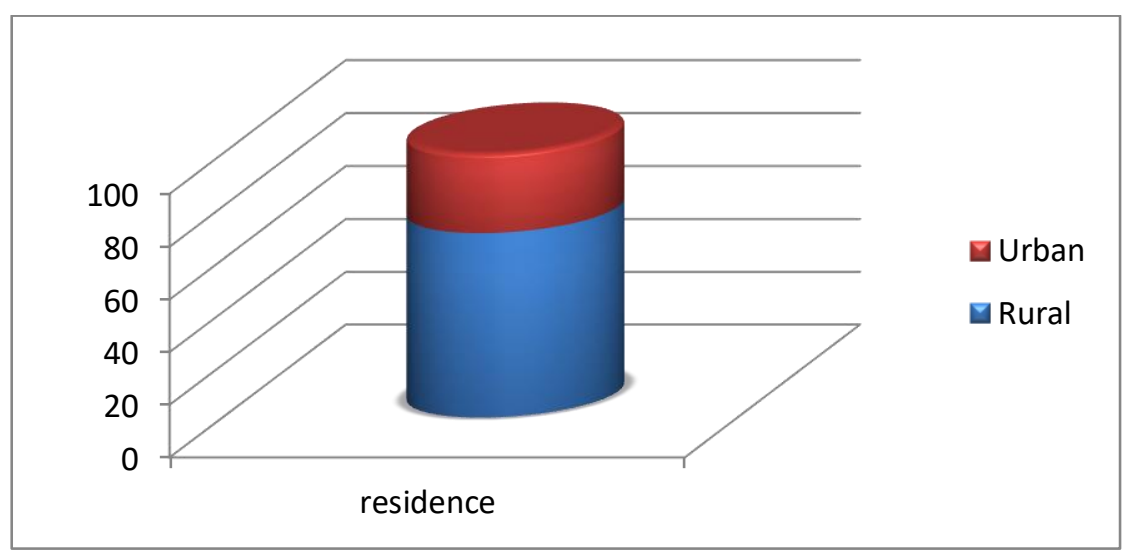

Fig. 4.1.2:-Illustrates the distribution of the clients according to the residence area. It reveals that, majority (93\%) were residing in urban and only $7 \%$ of the client were residing at rural.

Table 4.1.3:-Distribution of the clients according to the Monthly Income.

\begin{tabular}{|l|c|c|}
\hline Total Family Income & f & \% \\
\hline Less than Rs.5000 & - & - \\
\hline Rs.5001-10,000 & 5 & 16.7 \\
\hline Rs.10,001- 15,000 & 6 & 20 \\
\hline More than 15.000 & 19 & 63.3 \\
\hline
\end{tabular}

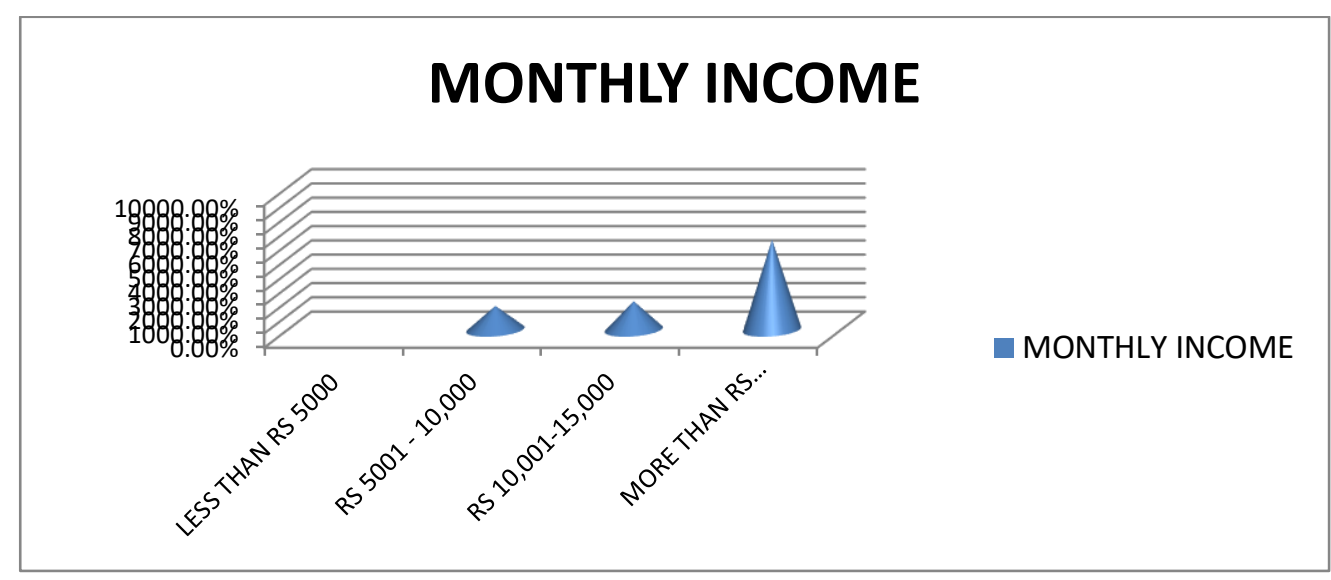

Fig. 4.1.3:- Shows distribution of the clients according to the monthly income. It depicts that majority (50\%) of the client earns between Rs.10, 001 - Rs. 15, 000 and $33 \%$ earns more than 15,000 and $17 \%$ earns between Rs. 5001-

$$
10,000 .
$$


Table 4.1.4:-Distribution of the clients according to the disease related variables

\begin{tabular}{|l|c|c|}
\hline Reason For Endoscopy & f & \% \\
\hline Stomach pain & 3 & 10 \\
\hline Blood vomiting & 3 & 10 \\
\hline Abdominal distension & 5 & 16.7 \\
\hline Others & 19 & 63.3 \\
\hline
\end{tabular}

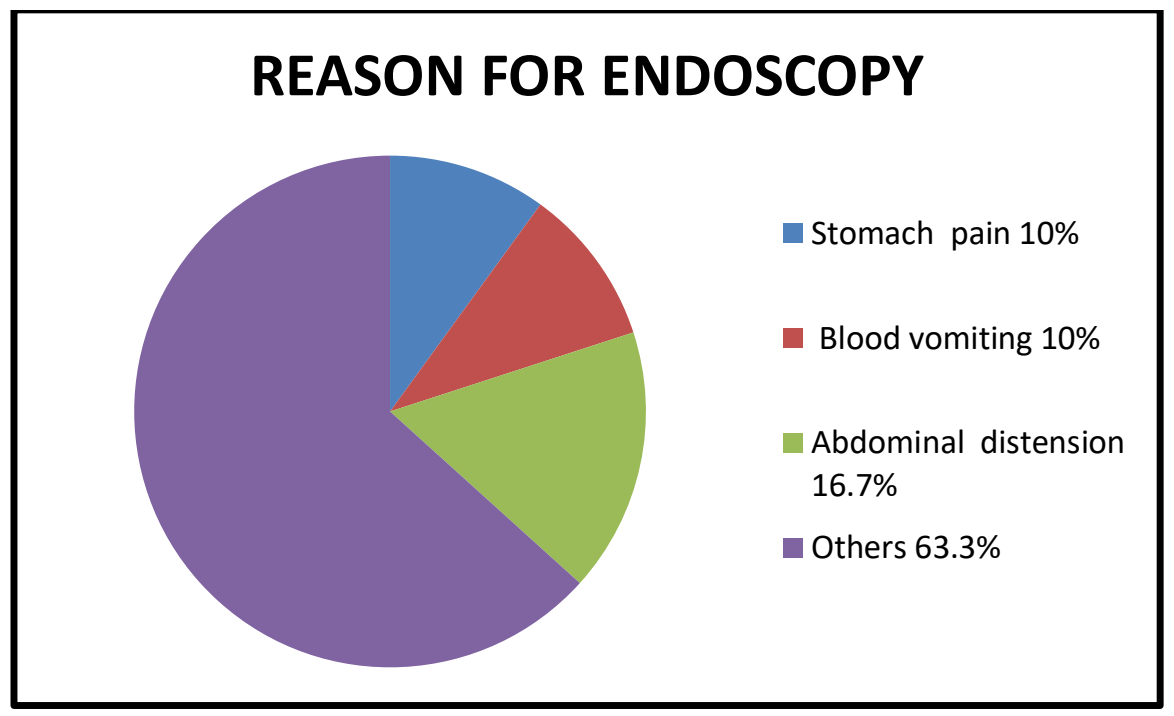

Fig. 4.1.4 :-Reveals that, majority (40\%) of the clients came for endoscopy with other gastro intestinal symptoms and $39 \%$ were came with complaints of stomach pain and $21 \%$ of the client came with abdominal distension.

Table 4.1.5:-Distribution of the clients according to the awareness to the procedure .

\begin{tabular}{|l|c|c|}
\hline AWARENESS & f & \% \\
\hline Health worker & 4 & 13.3 \\
\hline Family members & 2 & 6.7 \\
\hline Friends & 2 & 6.7 \\
\hline ass Media & 22 & 73.3 \\
\hline
\end{tabular}

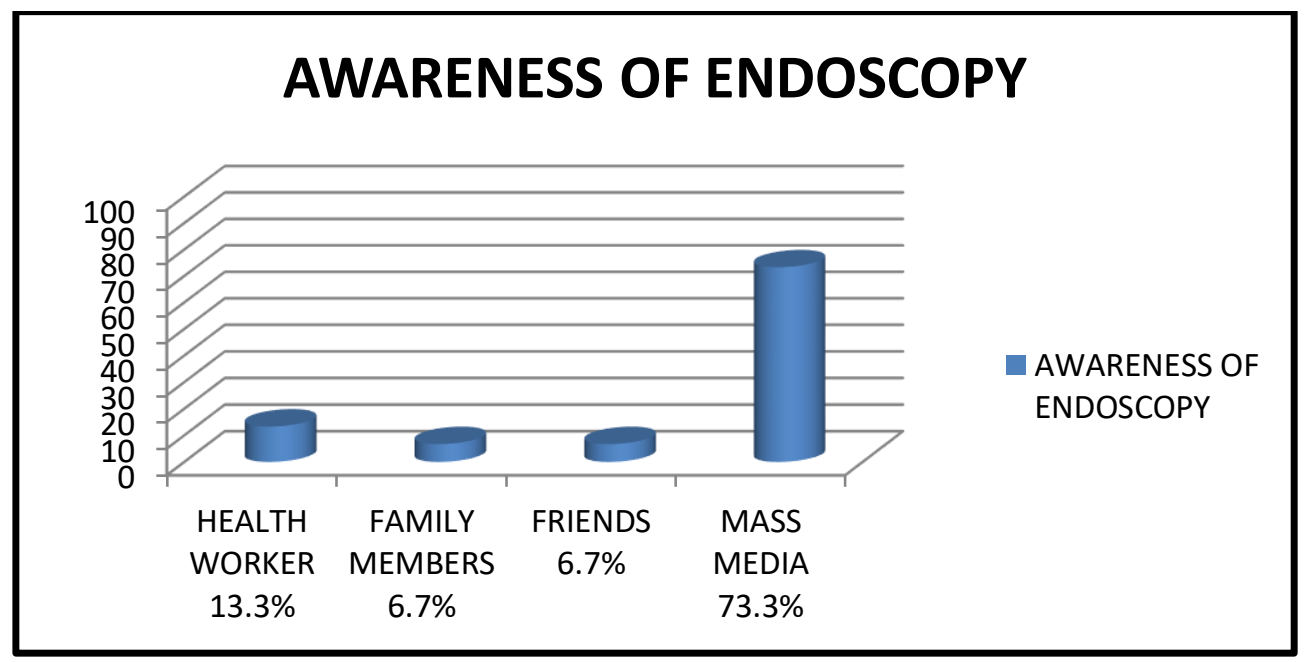

Fig. 4.1.5:-Depicts that, $86 \%$ of the clients were aware about the procedure, among them $55 \%$ heard through family members and $45 \%$ through friends. It concludes that majority of the clients were received the information through family members and from friends. 
Section B/ Objective. 1:

To assess the level of anxiety among clients undergoing upper gastro endoscopy.

Table 4. 2. 1:-Distribution of the level of anxiety for the client undergoing upper gastro endoscopy . ( $\mathrm{N}=30)$

\begin{tabular}{|l|l|l|}
\hline LEVEL OF ANXIETY & $\mathbf{f}$ & \% \\
\hline No anxiety (0-20) & 0 & - \\
\hline Mild anxiety (21-40) & 0 & - \\
\hline Moderate anxiety (41-60) & 28 & 93 \\
\hline Severe anxiety (61-80) & 2 & 7 \\
\hline
\end{tabular}

Table 4. 2. 1 shows the level of anxiety regarding upper gastro endoscopy clients. It reveals that majority (93\%) of them shows moderate anxiety and $7 \%$ shows severe level of anxiety.

\section{Section C/ Objective. 2:}

To associate the level of anxiety with selected demographic variables.

Table 4.3.1:-Distribution of the level of anxiety with selected demographic variables $\quad(\mathbf{N}=\mathbf{3 0})$

\begin{tabular}{|c|c|c|c|c|c|}
\hline \multirow{2}{*}{$\begin{array}{l}\text { DEMOGRAPHIC } \\
\text { VARIABLES }\end{array}$} & \multicolumn{5}{|c|}{ PRE-TEST } \\
\hline & MILD & MODERATE & $\begin{array}{c}\text { CHI } \\
\text { SQUARE }\end{array}$ & P-VALUE & $\begin{array}{l}\text { LEVEL OF SIGN- } \\
\text { FICANCE }\end{array}$ \\
\hline $\begin{array}{l}\text { AGE } \\
\text { 21-30 YEARS } \\
\text { 31-40 YEARS } \\
\text { 41-50 YEARS } \\
\text { 51-60 YEARS }\end{array}$ & $\begin{array}{l}8 \\
5 \\
0 \\
0\end{array}$ & $\begin{array}{c}11 \\
6 \\
0 \\
0\end{array}$ & 1.36 & 0.5055 & (N.S) \\
\hline $\begin{array}{l}\text { GENDER } \\
\text { MALE } \\
\text { FEMALE }\end{array}$ & $\begin{array}{l}8 \\
7\end{array}$ & $\begin{array}{l}6 \\
9\end{array}$ & 0.535 & 0.4642 & (N.S) \\
\hline $\begin{array}{l}\text { EDUCATIONAL STATUS } \\
\text { PRIMARY } \\
\text { SECONDARY } \\
\text { GRADUATE } \\
\text { POSTGRADUATE }\end{array}$ & $\begin{array}{c}19 \\
1 \\
2 \\
0\end{array}$ & $\begin{array}{l}8 \\
0 \\
0 \\
0\end{array}$ & 1.212 & 0.545 & (N.S) \\
\hline
\end{tabular}

( $\mathrm{P}<0.05$ Significant,$* *$ Highly significant, N.S= No Significant )

Table.4.3.1: Shows that there was no statistically significant association between the level of anxiety and the selected demographic variables of age, gender and educational status.

Table 4.3.2:-Distribution of the level of anxiety with selected demographic variables of residence, income and reson for endoscopy $\mathrm{n}=30$

\begin{tabular}{|l|l|l|l|l|l|}
\hline \multirow{2}{*}{$\begin{array}{l}\text { DEMOGRAPHIC } \\
\text { VARIABLES }\end{array}$} & $\begin{array}{l}\text { PRE - TEST } \\
\text { ANXIETY }\end{array}$ & $\begin{array}{l}\text { MODERATE } \\
\text { ANXIETY }\end{array}$ & $\begin{array}{l}\text { CHI } \\
\text { SQUARE }\end{array}$ & P-VALUE & $\begin{array}{l}\text { LEVEL OF SIGN- } \\
\text { FICANTS }\end{array}$ \\
\hline RESIDENCE & 3 & 18 & & & \\
RURAL & 5 & 4 & 5.48 & 0.119 & \\
URBAN & & & & & \\
& & & & & \\
\hline INCOME & 0 & 0 & & & \\
5000 AND LESS & 3 & 2 & 0.6739 & \\
5001-10000 & 4 & 2 & & & \\
10001-15000 & 9 & 10 & N.S) \\
MAORE THAN 15000 & 0 & 3 & & & \\
\hline REASON FOR ENDOSCOPY & 0 & 3 & 4.705 & 0.1947 & (N.S) \\
STOMACH PAIN & 0 & & & \\
BLOOD VOMITING & & & & & \\
\hline
\end{tabular}




\begin{tabular}{|l|l|l|l|l|l|}
\hline ABDOMINAL DISTENSION & 3 & 2 & & & \\
OTHERS & 7 & 12 & & \\
\hline
\end{tabular}

( $\mathrm{P}<0.05$ Significant,$* *$ Highly significant, N.S $=$ No Significant )

Table.4.3.2: Shows that there was no statistically significant association between the level of anxiety and the selected demographic variables of residence, income and reson for endoscopy.

Table 4.3.3:-Distribution of the level of anxiety with selected demographic variables source of information about endoscopy procedure. $n=30$

\begin{tabular}{|l|c|c|c|c|c|}
\hline DEMOGRAPHIC VARIABLES & MILD & MODERATE & $\begin{array}{c}\text { CHI } \\
\text { SQUARE }\end{array}$ & P-VALUE & $\begin{array}{c}\text { LEVEL OF } \\
\text { SIGN- } \\
\text { FICANTS }\end{array}$ \\
\hline SOURCEOF NFORMATION & 2 & 2 & & & \\
HEALTH PROFESSIONALS & 2 & 0 & 2.182 & 0.535 & (N.S) \\
FAMILY MEMBERS & 1 & 1 & & & \\
FRIENDS & 10 & 12 & & & \\
MASS MEDIA &
\end{tabular}

( $\mathrm{P}<0.05$ Significant,$* *$ Highly significant, N.S $=$ No Significant $)$

Table.4.3.3: Shows that there was no statistically significant association between the level of anxiety with the selected demographic variables .

Major findings of the study:-

1. Majority (33.3\%) of the clients were belongs to the age group of $31-40$ years, among that most of them were male and graduates.

2. According to the residence area., majority (93\%) were residing in urban and only $7 \%$ of the client were residing at rural.

3. Majority (50\%) of the client earns between Rs.10, 001 - Rs. 15, 000.

4. Most (76 \%) of the clients were alcoholic and with regards to the duration, greater part of the clients (56\%) were consuming alcohol for 1-5 years.

5. Greater part (40\%) of the clients came for endoscopy with other gastro intestinal symptoms and $86 \%$ of the clients were aware about the procedure, among them $55 \%$ heard through family members and $45 \%$ through friends.

6. According to the level of anxiety, majority (93\%) of them shows moderate anxiety and $7 \%$ shows severe anxiety towards the procedure..

7. There was no statistically significant association between the level of anxiety and the selected demographic variables of age, gender and educational status, residence, income and reason for endoscopy.

\section{Discussion:-}

This chapter attempts to discuss the finding of the study as per the objectives. The findings were discussed under the following headings.

1. Assessment of the level of anxiety among clients undergoing upper gastro endoscopy.

2. Associate the level of anxiety with selected demographic variables.

\section{Objective 1:}

Assessment of the level of anxiety among clients undergoing upper gastro endoscopy:

Anxiety is considered as one of the basic feelings in human. All of us experience anxiety in dangerous situations. High anxiety levels before medical or surgical interventions can lead to some undesirable results. So information before medical and surgical procedures helps to reduce the situational anxiety there by gains co-operation during the procedure and lessen procedure duration.

The study finding reveals, majority (93\%) of them shows moderate anxiety and $7 \%$ shows severe level of anxiety towards the procedure. Hence, it concluded that most of the clients were severely anxious about the procedure .

The study findings were consistent withMahmut arabul, August 2013 conducted a prospective study to assess the impact of information before unsedated upper gastrointestinal endoscopy on patient satisfaction and anxiety among four hundred and forty patients. The result reveals there was a significant difference in the patient watched $(\mathrm{p}=$ 
0.003). It concludes that information about the procedure helps to reduce the anxiety of the patient and increases patient satisfaction.

\section{Objective 2:}

Associate the level of anxiety with selected demographic variables:

Anxiety is a common problem in patients who have to undergo an invasive medical procedure .The increase in anxiety, stress, and decrease in tolerance, lead to unexpected changes in physiological status.

The study findings reveals that there was no statistically significant association between the level of anxiety and the selected demographic variables of age, gender and educational status, residence, income and reason for endoscopy.

The study findings supported withJulina Ongkasuwan, (2012) conducted a prospective case control study on physiologic impact of endoscopy at Baylor college of medicine, USA. The Result shows that, there was no statistically significant increase in $\mathrm{HR}$, change in $\mathrm{O}_{2}$ sat, blood pressure with selected demographic variables . It concludes that diagnostic endoscopy have no impact on physiologic parameters.

\section{Conclusion:-}

These findings of the study have been discussed in terms of the objectives and theoretical base. The following conclusion was drawn from the findings of the study: Majority (93\%) of the clients shows severe anxiety to the procedure.

\section{Bibliography:-}

1. Adams R et al. (2008), Methods in biostatistics for medical student and research workers, $6^{\text {th }}$ edition, New Delhi, Jaypee brothers publications.

2. Basavanthappa, B.T. (2003), Medical Surgical Nursing , $1^{\text {th }}$ Edition, New Delhi Jaypee Brothers Medical publishers.

3. Black M Joyce (2003), Medical Surgical Nursing clinical management for continuity of care. 3rd ed. New Delhi: W.B. Saunders Company.

4. Bob Elling, Kirsten (2004), Paramedic: anatomy and physiology, Canad, Jones and Bartlett publishers.

5. Carol Taylor, (1997), Fundamental of Nursing, $3^{\text {rd }}$ edition, Philadelphia , Lippincott publishers.

6. Denise F. Polite, (1999), Nursing Research, $6^{\text {th }}$ edition, Philadelphia, Lippincott publishers.

7. Davidson , ( 1995), Principles and Practice of Medicine, $7^{\text {th }}$ edition, Philadelphia, Churchill Livingstone publications.

8. Elakkuvana haskara raj ( 2010 ), Nursing research and biostatistics, $1^{\text {st }}$ edition, Bangalure, Emman publishers.

9. Geri lobiondo wood ( 2006 ), Nursing research and critical appraisal, $7^{\text {th }}$ edition, Missouri, Elseiwer publication.

10. Gerald J. Tortora ,(1999), Principals of a Human Anatomy, $8^{\text {th }}$ edition, New York, Addition Wesley Publications.

11. Harrison's, (2005), Principles of Internal Medicine, $16^{\text {th }}$ edition, New York, Mc Graw Hill medical publishers.

12. Harsh Mohan, (2005), The Book of Pathology, $5^{\text {th }}$ edition, New Delhi, Jaypee brother's medical publishers.

13. Joyce M.black, Jane Hokanson Hawks, Annabelle M.Kenne (2004), Medical Surgical Nursing Clinical Management for Positive outcomes, $7^{\text {th }}$ edition,Missouri, Elsevier publishers.

14. Juanita Watson, marie s ( 2001 ), Nurses manual of laboratory and diagnostic test, $2^{\text {nd }}$ edition, India, Jaypee brothers publicqation.

15. Karen j. Berger, (1992), Fundamental of Nursing", Norwalk, Applefon and Lange publishers.

16. Kothari, C.R.,(2008), Research methodology methods and techniques, $2^{\text {nd }}$ edition, New Delhi, New age International publishers.

17. Kozier Erb, (1995), Fundamental of Nursing, $5^{\text {th }}$ edition, New York, Addison - Wesley publishers.

18. Lewis, (2007), Medical Surgical Nursing- Assessment and management of

19. clinical problems, $7^{\text {th }}$ edition, New York, Mosby publications.

20. Luckman and Sorenesn's (1993), Medical Surgical Nursing, 4th edition, Philadelphia, W. B. Saunder's publishers.

21. Abraham NS, Fallone (2004). Sedation versus no sedation in the performance of

22. diagnostic upper gastrointestinal endoscopy: a Canadian randomized controlled cost-outcome study. Am J Gastroenterol, vol ; 99: page. no :1692- 9.

23. Baudet JS, Borque P, Borja E(2009), Use of sedation in gastrointestinal

24. endoscopy: a nationwide survey in Spain. Eur J Gastroenterol Hepatol, vol.; 21: page no: 882-8.

25. Bhalla A, Sachdev A, Sood A (2006). Cardiorespiratory compromise under

26. conscious sedation during upper gastrointestinal endoscopy. J Coll Physicians Surg Pak. Vol ;16: page no : 585-9.

27. Bonta PI, Kok MF, Bergman (2003), Conscious sedation for EUS of the 
28. esophagus and stomach: a double-blind, randomized, controlled trial comparing midazolam with placebo. Gastrointest Endoscopy. Journal of gastrology, Vol. 57: page no : 842-7

29. Brouillette DE, Leventhal R (2011). Midazolam versus diazepam for combined

30. esopho gastro duodenoscopy and colonoscopy. Jourmal of endoscopy. vol; 34: page :1265-71.

31. Cohen LB, Wecsler JS, Gaetano JN (2006) Endoscopic sedation in the US: results

32. from a nationwide survey. Am J Gastroenterology. Vol ;101: page no : 967-74.

33. COner N, Lecompte A. (2012), Factors predicting the possibility of conducting

34. colonoscopy without sedation. Journal of Endoscopy; vol. 32: page no : 688-92.

35. Eberhardt J, Van Wersch A (2006) . Information, social support and anxiety

36. before gastrointestinal endoscopy. Br J Health Psychology; vol. 11: page no : 551-9.

37. Freerman ML, Hennessy (2010). Carbondioxide retention and oxygen

38. desaturation during gastrointestinal endoscopy. Gastroenterology journal. Vol ; page no : 105:331-339

39. Gebbensleben B, Rohde H (2013), Gastrointestinalen Endoscopie ein

40. bedeutsames Problem?, jou Deutsche Medizinische Wochenschrift, vol: 115: page no :1539-44.

41. Gašparović S, Rustemović (2005), Clinical analysis of propofol deep sedation

42. for 1,104 patients undergoing gastrointestinal endoscopic procedures: A three year prospective study. World $\mathrm{J}$ Gastroenterol. vol;12: page no : 327-30.

43. Hamilton M (2002) "The assessment of anxiety states by rating.” Br J Med Psychology, vol . 32: page .no : 50-5.

44. Heuss LT, Froehlich F, Beglinger (2005 ). Changing patterns of sedation and

45. monitoring practice during endoscopy: results from a nationwide survey in Switzerland. Endoscopy journal. Vol ;37: page no : 161-6.

46. Jones MP, Ebert CC, Sloan (2004) “Patient anxiety and elective gastrointestinal endoscopy. J Clin Gastroenterol; Vol. 38:page no : 35-40.

47. Lazzaroni M, Bianchi (2011) . Preparation, premedication and surveillance. J Endoscopy.;35:103-11

48. Laluna L, Allen ML, Dimarino (2010), The comparison of midazolam and

49. topical lidocaine spray versus the combination of midazolam, meperidine, and topical lidocaine spray to sedate patients for upper endoscopy. Gastrointest Endosc. Vol ;53: page no :289-93.

50. Lazzaroni M, Bianchi Porro (2003), Preparation, premedication and surveillance. Journal of Endoscopy.vol;35: page no $: 103-111$

51. Madan A, Minocha A (2004) "Who is willing to undergo endoscopy without

52. sedation:patients, nurses, or the physicians?, South Med J, vol . 97 :page no: 800-5.

53. Malhotra HS, Rana (2010) . Electrocardiographic changes during upper

54. gastrointestinal endoscopy in ambient hypoxia. J Assoc Physicians India. 1vol ; 39: page no : $692-693$.

55. Mathew PK, Ona FV, Damvski(2011). Arrhythmias during upper gastrointestinal endoscopy. Angiology. Vol ;30:834-840.

56. Charalampos Mitsonis, (2011), Evaluated the relationship between pre endoscopic anxiety and panic attack during an elective gastrointestinal endoscopy, Glostrup Hospital, Greece.

57. Lilly Kutty (2005), The effectiveness of an information leaflet on awareness and satisfaction of patient undergoing upper gastrointestinal endoscopy, St. johns medical college hospital, Bangalore.

58. http://www.aao.org/practice_mgmt/patient_ed/effective.cfm

59. http://www.ncbi.nlm.nih.gov/pubmed/23161296

60. http://www.asge.org/patients/patients.aspx $\mathrm{id}=6928$

61. http://www.sciencedirect.com/science/article/pii/0738399188900729

62. http://onlinelibrary.wiley.com/doi/10.1046/j.1365-

63. http://www.jiscdigitalmedia.ac.uk/clinical-recordings/authors.html

64. http://www.jisc.ac.uk/events/making-and-using-clinical-and-healthcare-recordings-for-learning-and-teachingworkshop-20-sep

65. http://www.ncbi.nlm.nih.gov/pubmed/11298212

66. http://www.researchgate.net/publication/12124882

67. http://www.ncbi.nlm.nih.gov/pubmed/10728518

68. http://www.manipal.edu/institutions/nursing/mconmanipal/research/thesiscompleted/pages/mscnursingthesis2009.asp $\mathrm{X}$

69. http://wlv.openrepository.com/wlv/handle/2436/66633

70. http://informahealthcare.com/doi/abs/10.1080/00365520118872

71. http://www.sciencedirect.com/science/article/pii/S0194599807017081

72. http://www.ncbi.nlm.nih.gov/pmc/articles/PMC3203365/. 